Journal of Environmental
Analysis and Progress
ISSN: $2525-815 \mathrm{X}$

\title{
Diversity and Dominance in the phytoplankton community during nycthemeral cycles at different thermal patterns in the water body in the semiarid region of Brazil
}

Nísia Karine Cavalcanti Aragão-Tavares a, Ariadne do Nascimento Moura ${ }^{a}$, Silvano Lima do Nascimento Filho ${ }^{\mathrm{a}}$, Ênio Wocyli Dantas ${ }^{\mathrm{b}}$

a Universidade Federal Rural de Pernambuco-UFRPE, Departamento de Biologia, Área de Botânica. Rua Dom Manoel de Medeiros, s/n, Dois Irmãos, Recife-PE, Brasil. CEP: 52171-900. E-mail Corresponding Author: ariadne_moura@hotmail.com.

b Universidade Estadual da Paraíba-UEPB, Centro de Ciências Biológicas e Sociais Aplicadas-CCBSA, Departamento de Ciências Biológicas, Campus V. Rua Horácio Trajano de Oliveira, s/n, Cristo, João Pessoa, PB, Brasil. CEP: 58070450 .

\begin{tabular}{|c|c|}
\hline A R T I C L E I N F O & A B S T RA C T \\
\hline $\begin{array}{l}\text { Received 14 Jan } 2019 \\
\text { Accepted 15 Jan } 2019 \\
\text { Published 31 Jan } 2019\end{array}$ & $\begin{array}{l}\text { The vertical distribution of phytoplanktonic species in tropical regions responds } \\
\text { quickly to the physicochemical factors of water with ecophysiological changes and } \\
\text { biomass. Abiotic factors are responsible for the changes in the dominance of the } \\
\text { different groups. The study analyzed the diversity and dominance of the } \\
\text { phytoplankton community in a eutrophic reservoir localized in the semiarid region } \\
\text { of Brazil. The samplings were conducted in nycthemeral cycles in different thermal } \\
\text { regimes along a vertical profile. The biomass was determined by density and specific } \\
\text { biovolume. Patterns of richness, diversity and specific dominance index were } \\
\text { analyzed. The significant differences between the biotic data were analyzed by the } \\
\text { ANOVA two-way and t-test. Similarity matrices were plotted using the Jaccard and } \\
\text { Bray-Curtis indices with subsequent data ordination. } 33 \text { taxa were identified during } \\
\text { the study. Differences in thermal patterns that are occurring in nycthemeral cycles } \\
\text { showed changes in the structure of the phytoplankton community. The atelomictic } \\
\text { event contributed to changing of the algal structure, especially in biomass, } \\
\text { dominance, and diversity that shows significant differences between periods. The } \\
\text { lowest diversity reported (< } 1.03 \text { bits. } \text { L }^{-1} \text { ) were influenced by monospecific } \\
\text { dominance of the cyanobacteria } C \text {. raciborskii, thus recording greater biomasses, } \\
\text { forming blooms throughout the study period. In the tropical eutrophic reservoirs, an } \\
\text { algal bloom of cyanobacteria has persisted throughout the year, regardless of } \\
\text { variations in the thermal regime, thereby reducing the phytoplankton diversity. } \\
\text { Keywords: Atelomixia, cyanobacteria, daily cycles, eutrophic reservoir, thermal } \\
\text { profiles. }\end{array}$ \\
\hline
\end{tabular}

\section{Introduction}

In aquatic water bodies from tropical regions, especially reservoirs, thermal patterns related to the condition of stratification and interactions between the system of vertical mixing and the availability of light and nutrients, beyond the ecophysiological factors. Among these factors, the presence of structures such as aerotopes, and biotic relationships, as predation and herbivory (Elser \& Goldman, 1991; Reynolds, 2006) can interfere at the distribution and structure of phytoplankton in the water column (Tilzer \& Goldman, 1978; Kimmel et al., 1990; Calijuri et al.,
2002), establishing this way, the advantages of some species.

The physiological needs and responses that lead to changes, such as in diversity, biomass, taxonomic composition, dominance and patterns of vertical distribution of the phytoplanktonic species (Naselli-Flores \& Barone 2005; Naselli-Flores et al., 2007; Becker et al., 2008; Tolotti et al., 2010) are rapid, proportionate to the brief life cycle of this group of organisms, where the variations tend to be higher than in the nycthemeral cycles in seasonal scales (MacIntyre \& Melack, 1988). Thus, studies such as Becker et al. (2008), Borges et al. (2008), Bittencourt-Oliveira et al. (2012) have been 
conducted in nycthemeral scale $(24 \mathrm{~h})$ in order to understand the important questions about the dynamics of the algal community.

Throughout the studies into the behavior of phytoplankton in short time scale, some researchers have found the emergence of a pattern of differential thermal stratification in the tropical and subtropical systems of Brazil (Becker et al., 2008, 2009; Barbosa et al., 2011), known as atelomixis (Lewis, 1973). This phenomenon is characterized by daytime heating, and pronounced variability in wind speed, followed by nighttime cooling. It is responsible for a complex system and multiple thermoclines (Gunkel \& Casallas, 2002), resulting in stratification and destratification in the water column, and characterized for being a driving factor, selecting certain phytoplanktonic species (Reynolds, 1999; Barbosa \& Padisák, 2002).

This pattern of diurnal heating followed by a drop in temperature at night is common in the semi-arid region of northeastern Brazil. In this region, the reservoirs are characterized as eutrophic to hypertrophic, with consequent reduction in phytoplankton diversity and high biomass of cyanobacteria, leading to dominance of this group, which in turn, has been represented by one or a few species (Bouvy et al., 2000; Huszar et al., 2000; Chellappa \& Costa, 2003; Aragão et al., 2007; Moura et al., 2011; Chellappa et al., 2008; Dantas et al., 2011; Bittencourt-Oliveira et al., 2012, 2014).

Dominance of cyanobacteria and low diversity of phytoplankton frequently occur in tropical reservoirs, and because this, it was necessary to assess the behavior of these algae, in light of any changes in the thermal regime, the present study aims to determine the structure of the algal community in a eutrophic reservoir in northeastern Brazil, at different depths along the nycthemeral cycles, caused by presence or not of atelomixis.

This study tested the hypothesis: 1) the atelomictic process contributes to the increase in biomass and algal dominance, and the consequent reduction in phytoplanktonic diversity in eutrophic reservoirs in the semiarid of Brazil, assuming that: (a) the high algal biomass promoted by the cyanobacteria bloom event, reduces the diversity of algae; (b) the changes in the thermal pattern of the ecosystem influences the algal structure and modifies the diversity and dominance of phytoplanktonic community.

\section{Material and Methods Study area}

The study was conducted in Pedra reservoir $\left(08^{\circ} 29^{\prime} 35^{\prime \prime} \mathrm{S}\right.$ and $\left.36^{\circ} 56^{\prime} 39^{\prime \prime} \mathrm{W}\right)$, in Agreste mesoregion of the state of Pernambuco, Brazil. This region had a tropical rainy climate type BShs' (hot and dry), typical of semi-arid (Albuquerque \& Andrade, 2002), with two seasons: March through August (rainy) and September to February (dry). It has a maximum capacity of $2.9 \times 10^{6} \mathrm{~m}^{3}$, with an extension of $1.6 \mathrm{~km}$ and volume of $2,658 \mathrm{hm}^{3}$ (ANA, 2013), and $\mathrm{Zmax}=9 \mathrm{~m}(\mathrm{SRH}, 2012)$.

\section{Data collection}

Samplings collections were made in two climatic periods: August and December 2012, during nycthemeral cycles with intervals of four hours, beginning at $12 \mathrm{AM}$, considering light (8AM, 12AM and 4PM) and dark periods (8PM, 12PM and 4AM). Water samples were collected with van Dorn bottle in the limnetic region, at a fixed point near the dam at four depths: surface ( 0.1 $\mathrm{m})$, sub-surface $(0.5 \mathrm{~m})$, limit of the photic zone, estimated by the calculation proposed by Cole (1994), and aphotic layer (1 m above the sediment).

Vertical profiles with temperature and dissolved oxygen were carried from the surface to the aphotic layer, establishing intervals of $0.5 \mathrm{~m}$ to the depth of $5 \mathrm{~m}$, and from this to the aphotic layer, intervals of $1 \mathrm{~m}$.

The environmental data were analyzed only for the characterization of the environment. Some abiotic variables were determined in situ: water temperature $\left({ }^{\circ} \mathrm{C}\right)$ and dissolved oxygen (mg.L - $^{-1}$ ) using an oximeter (Schott, HandyLab OX1), the limit of the photic zone estimated by Cole (1994), Zmax using a bathymeter and electrical conductivity with a conductivity meter (HandyLab LF1). Turbidity (NTU) and $\mathrm{pH}$ were analyzed in situ with a turbidimeter (Hanna Instruments, HI 93703) and a potentiometer (Digimed, DMPH-2), respectively.

Analyses to assess the concentrations of nitrate- $\mathrm{NO}_{3}$, nitrite- $\mathrm{NO}_{2}$ (Mackereth et al., 1978), ammonia nitrogen- $\mathrm{NH}_{3}{ }^{+}$(Koroleff, 1976), orthophosphate- $\mathrm{PO}_{4}$ and total phosphorus-PT (Strickland \& Parsons, 1965) were measured at surface, subsurface, limit of the photic zone and aphotic layer in only one sampling collection $(12 \mathrm{PM})$, in both nycthemeral cycles.

The thermal patterns were determined from temperature profiles along the water column, and the stratification was considered stable when the average gradient showed a thermocline.

The phytoplankton was identified with the aid of specialized literature for each group of algae analyzing them to the lowest possible taxonomic level under a binocular microscope (Zeiss, Axiovert). The quantitative analysis was based on the counting of up to 400 organisms from the most frequent species (margin of error $\leq 10 \%$ ) (Lund et 
al., 1958), using an inverted microscope (Zeiss, Axiovert), method described by Utermöhl (1958).

Thirty individuals of abundant species and 10 of the rare species were measured to calculate the biovolume, following the method described by Sun \& Liu (2003). The biomass was determined from the density and specific cell biovolume is expressed in mg.L $\mathrm{L}^{-1}$ (Wetzel \& Likens, 2000).

\section{Statistical analysis}

The species richness $\left(\mathrm{n}^{\circ}\right.$ species) and Shannon diversity $\left(\mathrm{H}^{\prime}=-\Sigma\right.$ pi.log $\mathrm{pi}$; where, $\mathrm{pi}=$ ni/N, ni = biomass species; $\mathrm{N}=$ total sample biomass) (Shannon \& Weaver, 1949) were determined, to assess the variations in the composition and structure of the phytoplankton community. The Simpson index (D) was used to assess the dominant species by calculating $\mathrm{D}=\Sigma \mathrm{ni}$ (ni-1)/N(N-1).

Initially, the nycthemeral cycles were characterized based on the different thermal patterns. A two-criteria ANOVA analysis of variance was used per period to verify the significant differences based on data richness, diversity, dominance, and biomass between nycthemeral and depths. The t-test was used to assess the differences between these attributes at each depth between different thermal patterns.

The similarity of composition was analyzed using the matrices of the presence and absence of species, using the Jaccard index for depths, times and periods, and structure of phytoplankton, based on biomass, using data BrayCurtis. Subsequently, ordination of the data was performed using the non-metric multidimensional scaling (NMDS).

\section{Results}

This study revealed differences in thermal patterns that occur in the different nycthemeral cycles in semiarid reservoirs. During the rainy period, it was observed the presence of atelomictic phenomenon, characterized by the alternation of daytime thermal stratification (with thermocline set between depths of 0.5 to $1.5 \mathrm{~m}$ ) and destratification overnight, with cooling of the water column. While in dry the period, thermal stratification was marked throughout all hours of the cycle, not being registered atelomixis event (Figure 1).
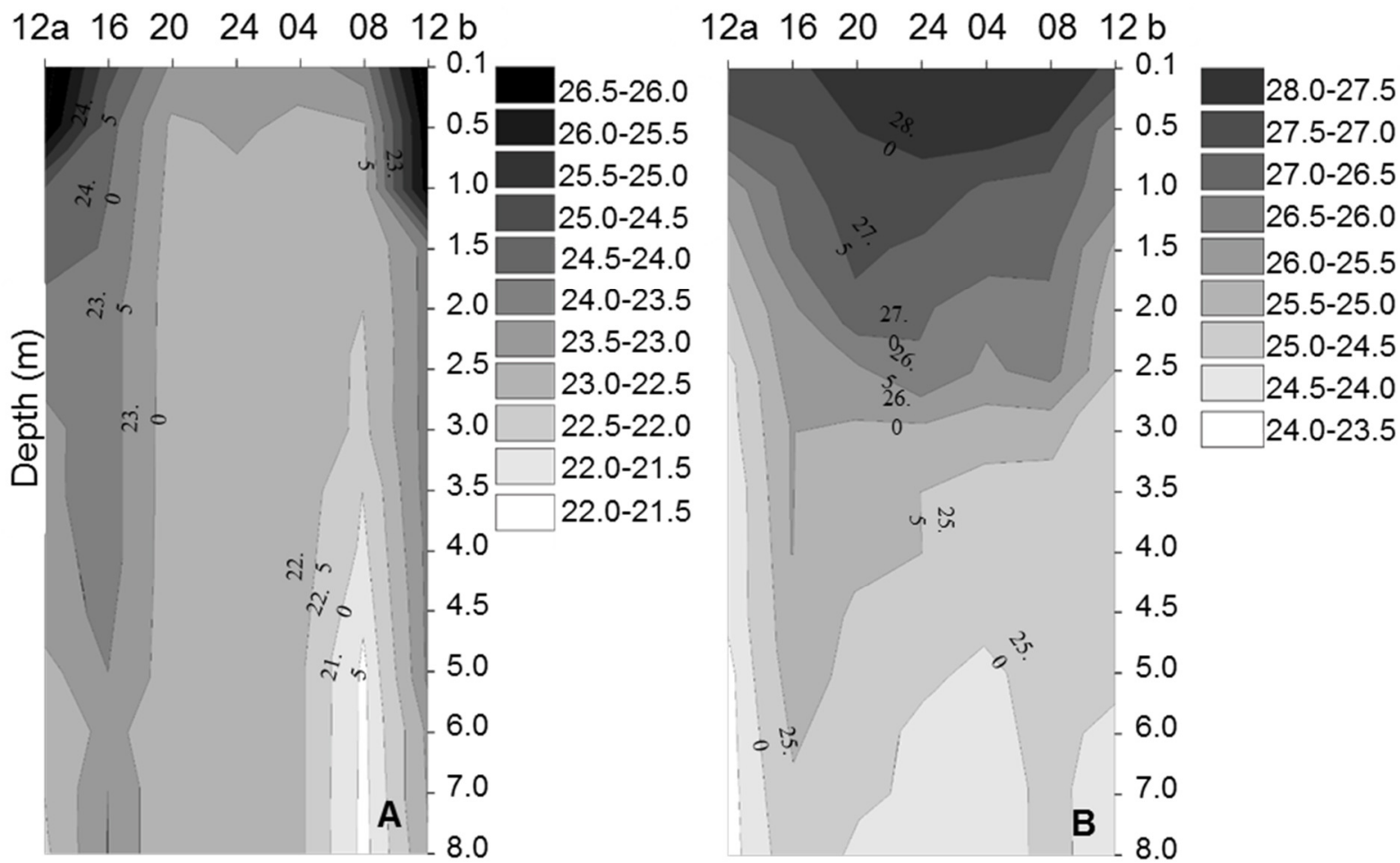

Figure 1. Thermal profile in nycthemeral cycles, (A) atelomictic (rainy season) and (B) non- atelomictic (dry), at different depths (over $8 \mathrm{~m}$ of the water column), at the Pedra reservoir, Northeast Brazil. Day interval (24 hours): $12 \mathrm{a}\left(12 \mathrm{PM}=1^{\text {st }}\right.$ sampling), $4 \mathrm{PM}, 8 \mathrm{PM}, 24 \mathrm{AM}, 4 \mathrm{AM}, 8 \mathrm{AM}, 12 \mathrm{~b}$ (12 PM = last sampling).

A similar pattern to the thermal profiles it was analyzed by dissolved oxygen concentration, the stratified periods was observed, both atelomictic as the non-atelomictic, differences between layers were observed, showing a clinograde profile, which showed destratification along the water column (Figure 2). 

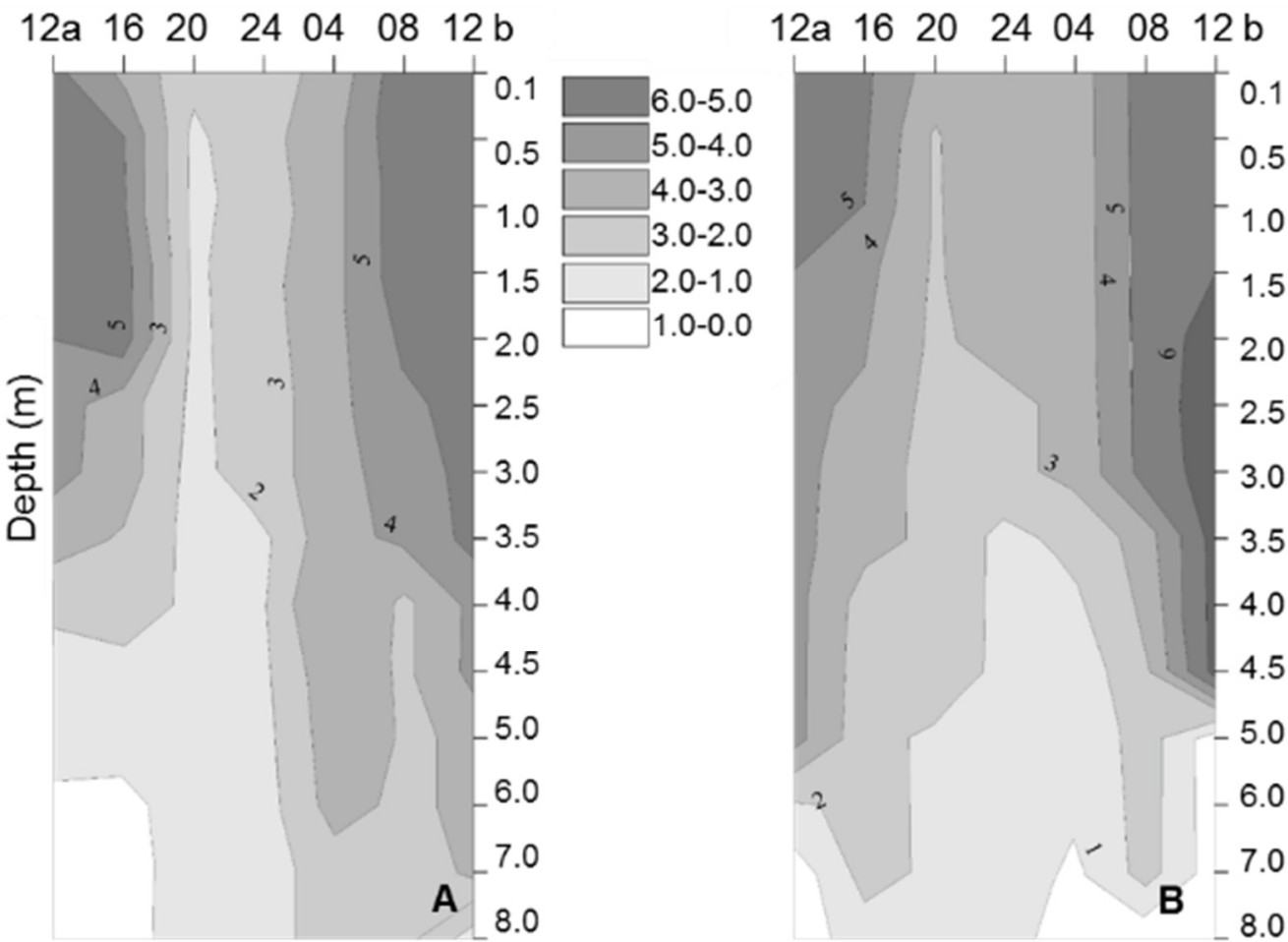

Figure 2. Dissolved oxygen profile in nycthemeral cycles, (A) atelomictic (rainy season) and (B) nonatelomictic (dry), at different depths (over $8 \mathrm{~m}$ of the water column), at the Pedra reservoir, Northeast Brazil. Day interval (24 hours): 12a (12PM = $1^{\text {st }}$ sampling), 4 PM, 8 PM, 24 AM, 4 AM, 8 AM, $12 \mathrm{~b}$ (12 PM = last sampling).

In both periods oxygen layers were assessed along the water column, especially in the epilimnion (3.8 - $6.6 \mathrm{mg} . \mathrm{L}^{-1}$ ), especially in daytime hours (8 AM to $4 \mathrm{PM}$ ), while the at deeper layer (8m) was recorded hypoxia $\left(0.2-2.5 \mathrm{mg} . \mathrm{L}^{-1}\right) ; \mathrm{pH}$ was neutral to alkaline at the two studied periods and all sampling depths (Table 1). Significant differences between depths were recorded only to dissolved oxygen $(\mathrm{F}=12,027.66 ; \mathrm{p}<0.05)$. However, among the nycthemeral cycles were observed differences in conductivity $(\mathrm{F}=49.60 ; \mathrm{p}$ $<0.05)$ and turbidity $(\mathrm{F}=10,877 ; \mathrm{p}<0.05)$, with higher values in the non-atelomictic period (stratified) (Table 1).

Regarding the nutrients, high concentrations of ammonia and total phosphorus were registred, in atelomictic and non- atelomictic periods, with higher values in the deeper layers $\left(\mathrm{NH}_{3}{ }^{+}: 1891 \mu \mathrm{g} . \mathrm{L}^{-1}\right.$; TP: $\left.204.8 \mu \mathrm{g} . \mathrm{L}^{-1}\right)$ and the photic zone $\left(\mathrm{NH}_{3}{ }^{+}: 1173.61 \mu \mathrm{g} . \mathrm{L}^{-1}\right.$; TP: $216.3 \mu \mathrm{g} . \mathrm{L}^{-}$ $\left.{ }^{1}\right)$, respectively, while the orthophosphate values presents higher during the period atelomictic (Table 1).

The phytoplankton community was composed by 33 taxa, distributed in six classes, Chlorophyceae (13 spp.), followed by Cyanophyceae (10 spp.). Twenty two taxa present in both study periods, demonstrating the low turnover of species throughout the study, as well as changes were not observed in composition or in the phytoplankton structure during nycthemeral cycle, and among the depths of the two cycles.

Cyanobacteria was present the largest phytoplankton biomass. In atelomictic period, a reduction in biomass was recorded along the depths and times of samplings, compare with those presented in the period non-atelomictic, the higher biomass was registred in atelomictic period (79.99 mg. $\mathrm{L}^{-1}$ ), while in the non-atelomictic was 125,470 mg. $\mathrm{L}^{-1}$, these biomasses were recorded at the 12aAM) (Table 2).

Considering a contribution above $5 \%$ of phytoplankton biomass, Cylindrospermopsis raciborskii (Woloszynska) Seenaya \& Subba Raju highlighted in both study periods, while Geitlerinema amphibium (Agardh ex Gomont) Anagnostidis occurred only in the non-atelomictic period.

The higher biomasses were $C$. raciborskii, considered the only dominant species in all samples (94\% of the biomass in the atelomictic cycle and $87 \%$ in the non-atelomictic), followed by G. amphibium, Microcystis sp., Planktothrix agardhii (Gomont) Anagnostidis \& Komárek, Phacus sp. and Staurastrum sp. (Table 2).

It was observed similarity in both the vertical distribution of the total phytoplankton biomass pattern especially $C$. raciborskii in 
atelomictic and non-atelomictic periods. In atelomictic event, a low vertical heterogeneity was recorded, throughout the cycle, already during the non-atelomictic, more evidenced stratifications were observed in the hypolimnion (Figure 3ab).

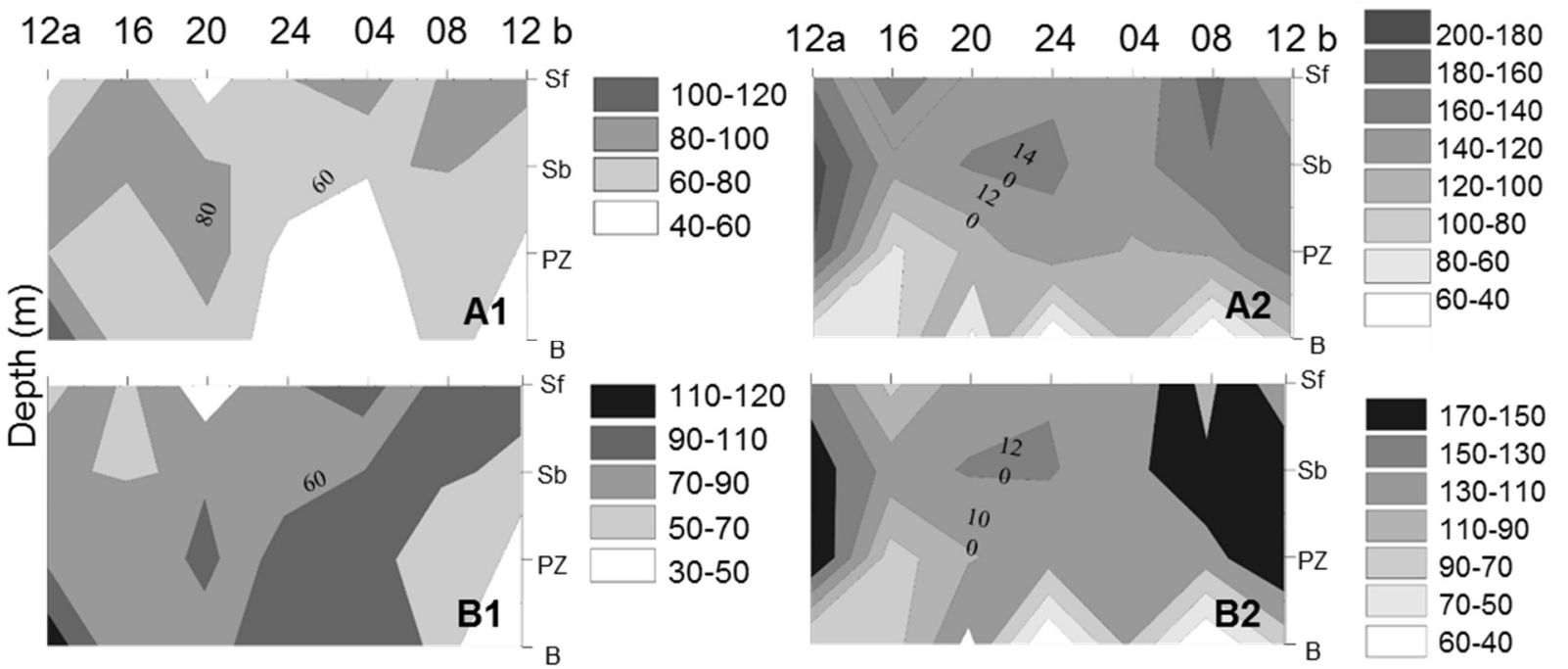

Figure 3. Depth-time diagrams of Phytoplankton. A. total biomass (mg. $\left.\mathrm{L}^{-1}\right)$; A1. in the atelomictic period; A2. in the atelomictic period; B. Biomass Cylindrospermopsis raciborskii; B1. in the atelomictic period; B2. in the atelomictic period, during a 24-hour cycle, at different depths (surface, subsurface, photic zone and bottom) at the Pedra reservoir, Northeast Brazil. Day interval (24 hours): $12 \mathrm{a}\left(12 \mathrm{PM}=1^{\text {st }}\right.$ sampling), $4 \mathrm{PM}, 8 \mathrm{PM}, 24$ $\mathrm{AM}, 4 \mathrm{AM}, 8 \mathrm{AM}, 12 \mathrm{~b}$ (12 $\mathrm{PM}=$ last sampling).

Lower diversity was observed throughout the study. The diversity index of the phytoplanktonic community was represented by values less than 1.03 bits. $L^{-1}$. Significant differences were observed between the hours $(\mathrm{p}<$ 0.01 ), and between the atelomictic and nonatelomictic periods (stratified) $(\mathrm{p}<0.01)$, with the lowest index observed in the atelomictic period (0.38-0.60 bits. $\left.\mathrm{L}^{-1}\right)$ (Table 2). The index of species dominance it was observed a variation between 0.73 to 0.93 along the samplings. Unlike the diversity index, there was an increase in species dominance during the atelomictic period (0.89-
$0.93)$, with significant differences between periods $(\mathrm{p}<0.01)$ (Table 2).

Based on the richness, it was observed a high similarity between the periods and samplings depths. The ordination of non-metric multidimensional scaling (NMDS) (stress, 0.3) showed a single group without the formation of defined groups (Figure 4a). Whereas based in the biomass data, it was observed a formation of two distinct groups corresponding to the atelomictic and non-atelomictic periods. The NMDS ordination showed a seasonal trend in the 1st axis (stress, 0.1) (Figure 4b).

Table 1. Means of physical and chemical variables of the Pedra reservoir, in Pernambuco State, during the atelomictic (August 2012) and non-atelomictic (December 2012) periods along the vertical gradient. Conductivity $\left(\mu \mathrm{S} . \mathrm{cm}^{-1}\right)$; D.O (Dissolved Oxygen). *(Sf-Surface, Sb-Subsurface, PZ-photic zone and Bbottom).

\begin{tabular}{lcccccccc}
\hline $\begin{array}{l}\text { Thermal pattern/ } \\
\text { abiotic variable }\end{array}$ & \multicolumn{3}{c}{ Atelomictic period } & & \multicolumn{3}{c}{ Non-atelomictic period } \\
\hline Conductivity & 209 & 220 & 220 & 243 & 261 & 258 & 258 & 249 \\
$\mathrm{D} . \mathrm{O}\left(\mathrm{mg} . \mathrm{L}^{-1}\right)$ & 4.16 & 4.33 & 4.37 & 1.35 & 4.83 & 4.7 & 4.48 & 0.81 \\
$\mathrm{pH}$ & 8.16 & 8.22 & 8.1 & 7.34 & 8.99 & 8.83 & 8.42 & 8.07 \\
Turbidity & 96.58 & 90.57 & 87.85 & 66.43 & 114.28 & 110.71 & 103.14 & 83.71 \\
$\mathrm{NO}_{3}\left(\mu \mathrm{g} . \mathrm{L}^{-1}\right)$ & 19.2 & 32.6 & 15.0 & 1.3 & 0.4 & 2.8 & 6.54 & 0.98 \\
$\mathrm{NO}_{2}\left(\mu \mathrm{g} . \mathrm{L}^{-1}\right)$ & 2.3 & 2.6 & 2.6 & 2.6 & 2.1 & 2.1 & 2.1 & 2.1 \\
$\mathrm{NH}_{3}{ }^{+}\left(\mu \mathrm{g} . \mathrm{L}^{-1}\right)$ & 423.4 & 348.7 & 441.5 & $1,891.6$ & 132.1 & 196.5 & $1,173.61$ & 122.7 \\
$\mathrm{TP}\left(\mu \mathrm{g} . \mathrm{L}^{-1}\right)$ & 157.4 & 142.4 & 134.9 & 204.8 & 144.2 & 182.8 & 216.3 & 162.2 \\
$\mathrm{PO}_{4}\left(\mu \mathrm{g} . \mathrm{L}^{-1}\right)$ & 113.2 & 94.1 & 98.9 & 130.8 & 21.6 & 18.7 & 47.55 & 21.62 \\
\hline
\end{tabular}


Table 2. Biomass (mg. $\left.\mathrm{L}^{-1}\right)$, diversity (bits. $\mathrm{L}^{-1}$ ) and dominance of the phytoplankton community of the Pedra reservoir, in Pernambuco State, in nycthemeral scale (4h intervals) during the atelomictic (August 2012) and non-atelomictic (December 2012) periods. Day interval (24 hours): $\mathrm{a}=1^{\text {st }}$ and $\mathrm{b}=$ last sampling; $+=$ taxa with biomass $<0.01 \mathrm{mg} . \mathrm{L}^{-1}$.

\begin{tabular}{|c|c|c|c|c|c|c|c|c|c|c|c|c|c|c|}
\hline \multirow{4}{*}{ Family/Species } & \multicolumn{14}{|c|}{ Biomass (mg.L ${ }^{-1}$ ) } \\
\hline & \multicolumn{7}{|c|}{ Atelomictic period } & \multicolumn{7}{|c|}{ Non-atelomictic period } \\
\hline & $12 \mathbf{a}$ & 4 & 8 & 24 & 4. & 8 & $12 b$ & $12 \mathbf{a}$ & 4 & 8 & 24 & 4 & 8 & $12 b$ \\
\hline & $\mathbf{A M}$ & $\mathbf{P M}$ & $\mathbf{P M}$ & $\mathbf{P M}$ & $\mathbf{A M}$ & $\mathbf{A M}$ & $\mathbf{A M}$ & $\mathbf{A M}$ & $\mathbf{P M}$ & $\mathbf{P M}$ & $\mathbf{P M}$ & $\mathbf{A M}$ & $\mathbf{A M}$ & $\mathbf{A M}$ \\
\hline \multicolumn{15}{|l|}{ Cyanophyceae } \\
\hline Aphanocapsa delicatissima & + & + & & + & 0.04 & & 0.01 & + & & + & + & 0.01 & + & 0.02 \\
\hline Chroococcus minutus & 0.02 & 0.04 & 0.04 & 0.03 & 0.04 & 0.04 & 0.03 & 0.11 & 0.05 & 0.14 & 0.15 & 0.07 & 0.10 & 0.03 \\
\hline Cylindrospermopsis raciborskii & 79.99 & 71.75 & 70.07 & 60.28 & 58.75 & 63.53 & 52.73 & 125.47 & 81.99 & 113.87 & 97.26 & 104.95 & 107.86 & 117.44 \\
\hline Dolichospermum sp. & & & & & & & & & 0.57 & & & & & \\
\hline Geitlerinema amphibium & 1.24 & 0.97 & 0.94 & 1.39 & 0.98 & 0.94 & 1.48 & 12.11 & 5.50 & 10.06 & 11.97 & 10.68 & 9.56 & 7.00 \\
\hline Merismopedia glauca & & & & & & & & & 0.02 & 0.11 & & & & \\
\hline Merismopedia tenuissima & 0.37 & 0.42 & 0.32 & 0.22 & 0.36 & 0.51 & 0.42 & 0.32 & 0.22 & 0.12 & 0.15 & 0.42 & 0.18 & 0.25 \\
\hline Microcystis sp. & 0.59 & 0.51 & 0.56 & 0.22 & 0.19 & 0.34 & 0.19 & 3.09 & 0.65 & 2.37 & 1.98 & 1.81 & 2.83 & 2.05 \\
\hline Planktothrix agardhii & 0.84 & 0.77 & 1.53 & 0.71 & 0.52 & 0.72 & 0.51 & 0.83 & 0.79 & 0.92 & 0.81 & 1.17 & 0.77 & 1.07 \\
\hline \multicolumn{15}{|l|}{ Chlorophyceae } \\
\hline Actinastrum sp. & & 0.12 & 0.08 & 0.09 & 0.12 & 0.08 & 0.07 & 0.11 & & 0.08 & 0.11 & & & \\
\hline Ankistrodesmus sp. & 0.13 & 0.39 & 0.14 & 0.05 & 0.03 & 0.12 & 0.05 & 0.12 & & 0.10 & & & 0.10 & \\
\hline Chlorella vulgaris & & & & & & & & 0.04 & & & 0.01 & & 0.04 & \\
\hline Closterium sp. & 0.09 & 0.13 & 0.10 & 0.09 & 0.11 & + & 0.07 & & & 0.11 & & & 0.04 & \\
\hline Coelastrum sp. & & & 0.05 & & 0.04 & & & & & & & & 0.10 & \\
\hline Crucigenia fenestrata & + & 0.02 & 0.02 & 0.01 & 0.04 & + & 0.02 & 0.08 & 0.05 & 0.02 & 0.02 & 0.02 & 0.03 & 0.04 \\
\hline Golenkinia radiata & & & & & & & & & & & & + & & + \\
\hline Kirchneriella sp. & + & + & + & + & + & + & & & + & + & & & & + \\
\hline Monoraphidium arcuatum & 0.06 & 0.14 & 0.19 & 0.09 & 0.13 & 0.13 & 0.11 & 0.71 & 0.37 & 0.65 & 0.44 & 0.60 & 0.62 & 0.62 \\
\hline Monoraphidium contortum & 0.03 & & & & & & & & & & & & & \\
\hline Monoraphidium griffithii & & & & & & 0.03 & 0.01 & & & & 0.06 & & & \\
\hline Scenedesmus sp. & 0.14 & 0.02 & 0.15 & 0.12 & & 0.14 & & 0.14 & 0.17 & & & 0.16 & & 0.22 \\
\hline Staurastrum sp. & & & & & & & & 2.32 & & 1.39 & & 1.82 & 2.65 & 1.55 \\
\hline \multicolumn{15}{|l|}{ Bacillariophyceae } \\
\hline Aulacoseira granulata & & & & & & & & & & 0.01 & & & & \\
\hline Cyclotella meneghiniana & & & & & & & & 0.23 & & & & & & \\
\hline Nitzschia palea & 0.02 & & & & & & & & & 0.03 & & & & \\
\hline Surirella sp. & & & & & & & & & 0.01 & & 0.10 & & & \\
\hline Ulnaria ulna & 0.09 & 0.09 & 0.09 & 0.09 & & 0.09 & 0.08 & 0.19 & 0.7 & 0.25 & 0.12 & 0.27 & 0.20 & 0.18 \\
\hline Euglenophyceae & & & & & & & & & & & & & & \\
\hline Euglena acus & & & 0.07 & & & & 0.18 & & & & & & & \\
\hline Phacus sp. & 0.61 & 1.08 & 1.38 & & & & 0.75 & 1.82 & & 1.56 & 5.28 & 2.31 & 1.93 & 2.60 \\
\hline
\end{tabular}


Trachelomonas $\mathrm{sp}$

0.05

$0.17 \quad 0.05 \quad 0.06$

Dinophyceae

0.08

$0.07^{0} 0.11^{0} 0.07$

Cryptophyceae

0.08

0.05

$0.40 \quad 0.08$

13

$\begin{array}{lll}0.23 & 0.11 & 0.11 \\ \mathbf{1 . 0 2} & \mathbf{0 . 9 7} & \mathbf{0 . 9 6}\end{array}$

0.16

Diversity

$\begin{array}{ll}0.14 & 0.19 \\ \mathbf{0 . 4 9} & \mathbf{0 . 5 6}\end{array}$

$\begin{array}{lll}0.60 & 0.43 & 0.38\end{array}$

$\begin{array}{ll}0.43 & 0.56\end{array}$

1.01

$\begin{array}{ll}0.71 & 0.89 \\ 0.83 & 0.78\end{array}$

0.77

0.81
0.81
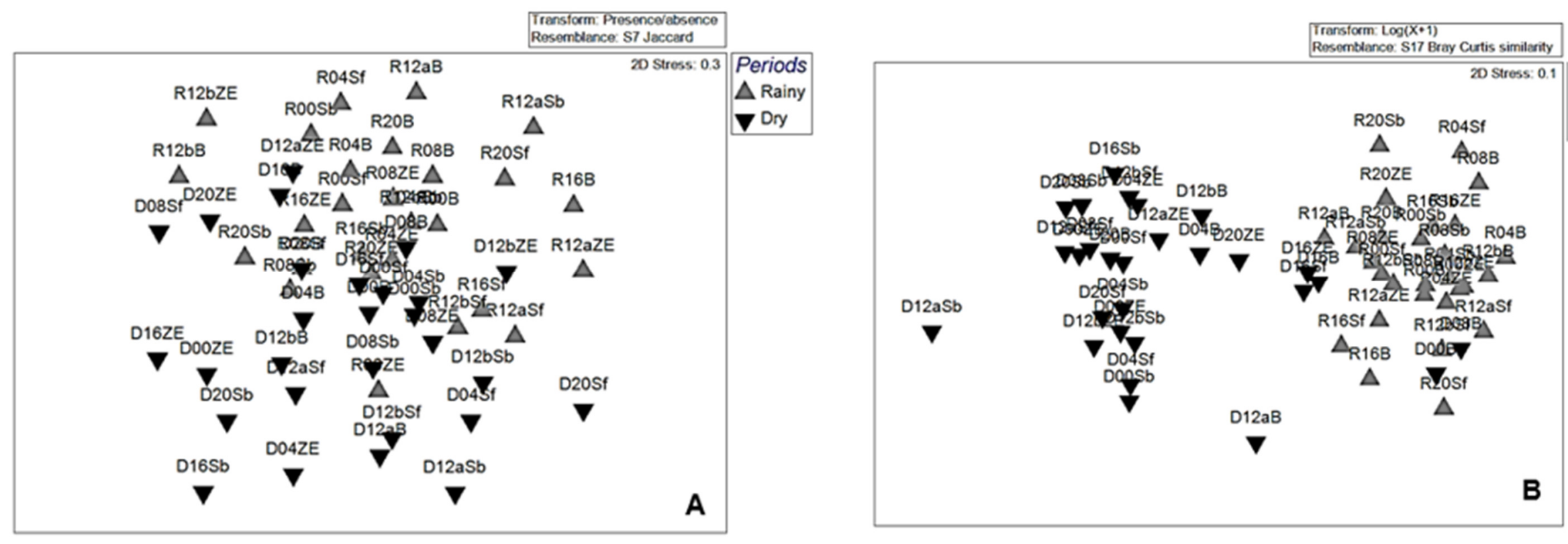

Figure 4. NMDS ordination of phytoplankton community during atelomictic and non-atelomictic periods, in temporal and spatial dynamics with data based on the Jaccard richness index (A) and Bray-Curtis biomass (B). D (dry period- non-atelomictic), R (rainy period- atelomictic); Day interval $\left(24\right.$ hours): $12 \mathrm{a}\left(12 \mathrm{PM}=1^{\text {st }}\right.$ sampling), 4PM, 8PM, 24AM, 4AM, 8AM, 12b (12PM = last sampling); Depth (Sf-Surface, Sb-Subsurface, ZE-photic zone and B-bottom). 


\section{Discussion}

The Pedra reservoir may be considered a tropical ecosystem, eutrophic and shallow, has been characterized by changes in community structure, which are directly related to the different thermal patterns (Bouvy et al., 2000; Pannard et al., 2008; Dantas et al., 2011).

These distinct patterns were found throughout the cycles nycthemeral, which could be classified into atelomictic and non-atelomictic period. The atelomictic characterized by alternating temperatures where the diel heating causes superficial stratification, followed by overnight cooling with mixing, promoted by temperature decrease, can change the biotic and abiotic conditions along the water column (Lewis, 1973; Barbosa \& Padisák, 2002) the nonatelomictic period, was marked only by the presence of thermal stratification throughout the nycthemeral cycle.

According Esteves (1998), atelomictic event were characterized by typical polymictic hot water ecosystems, which have repeated periods of movement and short heating intervals with light layering, followed by rapid cooling of the water column. This scenery has been observed by several researchers (Barbosa \& Padisák, 2002; Lopes et al., 2005; Tavera \& Martínez-Almeida, 2005; Souza et al., 2008; Becker et al., 2009; Lopes et al., 2009; Barbosa et al., 2011; Borics et al., 2011), which highlight the influence of this phenomenon in the distribution of phytoplankton along the water column, as a driver factor species-specific.

The atelomictic phenomenon, according to Bouvy et al. (2003), occurs due the changes in the density of water in the surface layers, promoted by the increase of the air temperature and the incidence of light during the day, forming layers that are dissolved with cooling at night. Studies has indicated that in aquatic ecosystems, mainly tropical, there is permanent thermocline in a seasonal period, i.e., stratification, and in another period, there is the presence of atelomixis (Barbosa \& Padisák, 2002; Bouvy et al., 2003; Lopes et al., 2005; Becker et al., 2008; Souza et al., 2008; Lopes et al., 2009; López et al., 2012). Some of these argue that this phenomenon presents a controlling factor for maintaining species listings in the epilimnion during periods of thermal stratification, thus bringing the success of Chlorophyceae species in these environments (Barbosa \& Padisák, 2002; Souza et al., 2008; López et al., 2012). In Pedra reservoir, although wealth has been represented mostly by Chlorophyceae, but this group did not contribute with representatives' biomasses.

The different periods analyzed were not marked by destratification during the rainy period and stratification during the dry period, related to seasonal thermal pattern, as observed for others works to the tropics (Barbosa et al., 2011; Dantas et al., 2011; Bittencourt-Oliveira et al., 2012). In this study, the atelomictic event in rainy season, may have occurred because of hydrological changes (severe droughts throughout the year, making it atypical), and probably this thermal condition has not contributed strongly to changes in most physical and chemical conditions between the two periods, and therefore has not promoted changes on the composition and species dominance.

Regarding abiotic variables, it was found that the pattern of chemical stratification, in dissolved oxygen concentration, followed the pattern of thermal stratification, revealing a clinograde profile with oxygen deficit, especially in the hypolimnion. While the stage with destratification (atelomictic period, at night) was demonstrated a trend variable homogeneity throughout the water column.

According to Esteves (1998), the oxygen deficit is mainly determined by high temperatures, by morphometric characteristics, which hinder or facilitate the action of wind, and high concentration of organic matter in the aquatic ecosystem. Concerning $\mathrm{pH}$, this appeared neutral to alkaline, characteristic buffered environments in both nycthemeral cycles.

The electrical conductivity and turbidity were presents higher concentrations during nonatelomictic period (stratified), this is because they are associated with low rain fall, evaporation rate, and possible exogenous contributions by human action, especially the entry of domestic sewage and runoff water. The increase of nutrient concentrations is also favored by these actions, promoting artificial eutrophication, and hence siltation and death of the water body (Margalef, 1983). In this study we showed higher ammoniacal nitrogen and total phosphorus concentrations in the hypolimnion, during the atelomictic period, and at metalimnion, during non-atelomictic. Besides these, was also found higher concentrations of orthophosphate during the event with atelomixis.

It was expected that, during the atelomictic period, a greater input of nutrients along the water column, due the resuspension of the pellet process (Chellappa \& Costa, 2003). This condition favors important misture of the water column, changes in light availability in the epilimnion, vertical gradient of other abiotic factors, and changes in the structure of algal, as replacement of cyanobacteria by other phytoplankton groups or even by other species of cyanobacteria (Heo \& Kim, 2004; Becker et al., 2008; Dantas et al., 2011). 
During the atelomictic and non-atelomictic periods, changes in the structure of phytoplankton was observed in biomass, diversity and dominance, since a reduction in the diversity and biomass was observes at the atelomictic period, with a consequent increase in species dominance. Although there was a decrease in the biomass in this period, throughout the study, blooms with monospecific dominance of cyanobacteria $C$. raciborskii, which persisted throughout the period. In Northeast Brazil ecosystems, the only event of dominance, throughout the year, it has been registered, with variations in biomass may be related to changes in temperature or thermal patterns (Bouvy et al., 1999; Huszar et al., 2000; Dantas et al., 2011).

The dense development of $C$. raciborskii was also recorded by Shafik et al. (2001) during the atelomictic event, but the authors did not associate the occurrence of this cyanobacteria with thermal event, but the fact of this species is adapted to different environmental conditions, like low luminosity.

Bittencourt-Oliveira et al. (2012) other semiarid reservoir, observed changes in composition and biomass of cyanobacteria during stratification and destratification periods, with marked by seasonal differences, without occurrence of atelomictic phenomenon. In this work it was observed that during the stratification period, occurred the dominance of $C$. raciborskii, and during destratification occurred, a reduction of algal biomass, although the dominance of cyanobacteria has persisted throughout the study period.

According to Melack (1979), tropical lakes are generally ecosystems exposed to low climate variability, which has directed a low diversity of species, due the persistence of one or few phytoplankton species. The dominance and persistence observed in this work, specifically to $C$. raciborskii occurred regardless of the particular pattern of atelomixis and can thus interpret different thermal patterns, and in some cases do not interfere with the establishment of algae.

In eutrophic-hypertrophic reservoirs in the Northeast, it is common the presence of perennial blooms formed by one or several species of cyanobacteria that can regulate their position in the column, because this species normally have vacuoles that aids in buoyancy (Moura et al., 2011). Among these, C. raciborskii is a species often found in these environments (Bouvy et al., 2000; Chellappa \& Costa, 2003; Von Sperling et al., 2008; Moura et al., 2011), and its persistent dominance can be attributed to great and frequent temperature conditions, as well as tolerance to low light intensity.

The low diversity values observed throughout the study were therefore influenced by the low richness and dominance of only one specie (C. raciborskii), corroborated with Calijuri \& Dos Santos (1996) and Dos Santos \& Calijuri (1998), which showed low fluctuations in the structure of phytoplankton. According to Holzmann (1993), the low diversity occurs when the conditions select few species which dominate the environment and the effect of predation becomes resistant. Thus, the decrease in phytoplankton diversity is attributed to the formation of algal blooms, thereby contributing to a negative ecological impact on the aquatic ecosystems.

\section{Conclusion}

Differences in thermal patterns that occurring in nycthemeral cycles showed changes in the structure of the phytoplankton community. In the present study, the atelomictic event contributed in changing of the algal structure, especially in biomass, dominance and diversity that shows significant differences between periods.

In a less stable thermal condition, such as the atelomictic event, the reduction of diversity has led to the increased dominance of $C$. raciborskii and can thus be concluded that during this period, a greater adaptation of this dominant species occurs, even though the biomass was lower in the stratified period.

Although the biomass values were elevated throughout the work, during the atelomixis event, it was observed formation of multiple thermoclines with diurnal stratification followed by destratification at night, there was a reduction in algal biomass at all sampling depths, and it can be thus observed that this change occurred as a result of the mobility of organisms in the water column in a nycthemeral cycle.

Dominance of cyanobacteria has persisted, performing at steady state, throughout the year, regardless of the variations in thermal regime, thereby reducing the phytoplankton diversity.

\section{Acknowledgements}

This research was supported by grants from the Coordenação de Apefeiçoamento de Pessoal de Nível Superior (CAPES) and Conselho Nacional de Desenvolvimento Científico e Tecnológico $(\mathrm{CNPq})$ for financial support (Proc. 301715/2008-4, 302068/2011-2 and 471603/2012$0)$. 


\section{References}

ALBUQUERQUE, U. P.; ANDRADE, L. D. H. C. 2002. Conhecimento botânico tradicional e conservação em uma área de caatinga no estado de Pernambuco, Nordeste do Brasil. Acta Botanica Brasilica, v. 16, n. 3, p. 273-285.

ANA-Agência Nacional das Águas. 2013. Boletim de Acompanhamento dos Reservatórios do Nordeste, v. 8, p. 1-16. Available in: http://arquivos.ana.gov.br/saladesituacao/Boletins Mensais/ReservatorioNordeste/Boletim_Monitora mento_Reser_Nordeste_2013_0107.pdf.

ARAGÃO, N. K. C. V.; GOMES, C. T.; LIRA, G. A.; DE ANDRADE, C. M. 2007. Estudo da comunidade fitoplanctônica no reservatório do Carpina-PE, com ênfase em Cyanobacteria. Revista do Instituto Adolfo Lutz, v. 66, n. 3, p. 240248.

BARBOSA, F. A.; PADISÁK, J. 2002. The forgotten lake stratification pattern: atelomixis, and its ecological importance. Internationale Vereinigung für theoretische und angewandte Limnologie: Verhandlungen, v. 28, n. 3, p. 13851395.

BARBOSA, L. G.; BARBOSA, P. M. M.; BARBOSA, F. A. R. 2011. Vertical distribution of phytoplankton functional groups in a tropical shallow lake: driving forces on a diel scale. Acta Limnologica Brasiliensia, v. 23, n. 1, p. 63-73.

BECKER, V.; HUSZAR, V. L. M.; NASELLIFLORES, L. U. I. G. I.; PADISAK, J. 2008. Phytoplankton equilibrium phases during thermal stratification in a deep subtropical reservoir. Freshwater Biology, v. 53, n. 5, p. 952-963.

BECKER, V.; DE SOUZA CARDOSO, L.; HUSZAR, V. L. M. 2009. Diel variation of phytoplankton functional groups in a subtropical reservoir in southern Brazil during an autumnal stratification period. Aquatic Ecology, v. 43, n. 2, p. 285-293.

BITTENCOURT-OLIVEIRA, M. C.; DIAS, S. N.; MOURA, A. N.; CORDEIRO-ARAÚJO, M. K.; DANTAS, E. W. 2012. Seasonal dynamics of cyanobacteria in a eutrophic reservoir (Arcoverde) in a semi-arid region of Brazil. Brazilian Journal of Biology, v. 72, n. 3, p. 533-544.

BITTENCOURT-OLIVEIRA, M. A. R. I. A.; CARMO, D.; PICCIN-SANTOS, V. I. V. I. A. N. E.; MOURA, A. N.; ARAGÃO-TAVARES, N. K.;
CORDEIRO-ARAÚJO, M. K. 2014. Cyanobacteria, microcystins and cylindrospermopsin in public drinking supply reservoirs of Brazil. Anais da Academia Brasileira de Ciências, v. 86, n. 1, p. 297-310.

BORGES, P. A. F.; TRAIN, S.; RODRIGUES, L. C. 2008. Spatial and temporal variation of phytoplankton in two subtropical Brazilian reservoirs. Hydrobiologia, v. 607, n. 1, p. 63-74.

BORICS, G.; ABONYI, A.; KRASZNAI, E.; VÁRBÍRÓ, G.; GRIGORSZKY, I.; SZABÓ, S.; DEÁK, C.; TÓTHMÉRÉSZ, B. 2011. Small-scale patchiness of the phytoplankton in a lentic oxbow. Journal of Plankton Research, v. 33, n. 6, p. 973981.

BOUVY, M.; MOLICA, R.; DE OLIVEIRA, S.; MARINHO, M.; BEKER, B. 1999. Dynamics of a toxic cyanobacterial bloom (Cylindrospermopsis raciborskii) in a shallow reservoir in the semi-arid region of northeast Brazil. Aquatic Microbial Ecology, v. 20, n. 3, p. 285-297.

BOUVY, M.; FALCÃO, D.; MARINHO, M.; PAGANO, M.; MOURA, A. 2000. Occurrence of Cylindrospermopsis (Cyanobacteria) in 39 Brazilian tropical reservoirs during the 1998 drought. Aquatic Microbial Ecology, v. 23, n. 1, p. 13-27.

BOUVY, M.; NASCIMENTO, S. M.; MOLICA, R. J.; FERREIRA, A.; HUSZAR, V.; AZEVEDO, S. M. 2003. Limnological features in Tapacurá reservoir (Northeast Brazil) during a severe drought. Hydrobiologia, v. 493, n. 1, p. 15-130.

CALIJURI, M. C.; DOS SANTOS, A. C. A. 1996. Short-term changes in the Barra Bonita reservoir (São Paulo, Brazil): emphasis on the phytoplankton communities. Hydrobiologia, v. 330, n. 3, p. 163175.

CALIJURI, M. D. C.; DOS SANTOS, A. C. A.; JATI, S. 2002. Temporal changes in the phytoplankton community structure in a tropical and eutrophic reservoir (Barra Bonita, SP-Brazil). Journal of Plankton Research, v. 24, n. 7, p. 617634.

CHELlAPPA, N. T.; COSTA, M. A. M. 2003. Dominant and co-existing species of Cyanobacteria from a Eutrophicated reservoir of Rio Grande do Norte State, Brazil. Acta Oecologica, v. 24, p. 3-10. 
CHELLAPPA, N. T.; BORBA, J. M.; ROCHA, O. 2008. Phytoplankton community and physicalchemical characteristics of water in the public reservoir of Cruzeta, RN, Brazil. Brazilian Journal of Biology, v. 68, n. 3, p. 477-494.

COLE, G. A. 1994. Textbook of limnology. 4th ed., Long Grove: Waveland Press. 412p.

DANTAS, E. W.; MOURA, A. N.; BITTENCOURT-OLIVEIRA, M. D. C. 2011. Cyanobacterial blooms in stratified and destratified eutrophic reservoirs in semi-arid region of Brazil. Anais da Academia Brasileira de Ciências, v. 83, n. 4, p. 1327-1338.

DOS SANTOS, A. C. A.; CALIJURI, M. C. 1998. Survival strategies of some species of the phytoplankton community in the Barra Bonita Reservoir (São Paulo, Brazil). Hydrobiologia, v. 367, n. 3, p. 139-151.

ELSER, J. J.; GOLDMAN, C. R. 1991. Zooplankton effects on phytoplankton in lakes of contrasting trophic status. Limnol. Oceanogr., v. 36, p. 64-90.

ESTEVES, F. A. 1998. Fundamentos de Limnologia. Rio de Janeiro: Interciências. 2nd ed. $575 p$.

GUNKEL, G.; CASALLAS, L. 2002. Limnology of an equatorial high mountain lake - Lago San Pablo, Ecuador: The significance of deep diurnal mixing for lake productivity. Limnologica, v. 32, p. 33-43.

HEO, W.; KIM, B. 2004. The effect of artificial destratification on phytoplankton in a reservoir. Hydrobiologia, v. 524, p. 229-239.

HOLZMANN, R. 1993. Seasonal fluctuations in the diversity and compositional stability of phytoplankton communities in small lakes in upper Bavaria. Hydvobiologia, v. 249, p. 101-109.

HUSZAR, V. L. M.; SILVA, L. H. S.; MARINHO, M.; DOMINGOS, P.; SANT'ANNA, C. L. 2000. Cyanoprokaryote assemblages in eight productive tropical Brazilian waters. In: REYNOLDS, C. S.; Dokulil, M.; Padisák, J. (Eds.). The Trophic Spectrum Revisited. pp. 67-77. Springer, Dordrecht.

KIMMEL, B. L.; LIND, O. T.; PAULSON, L. J. 1990. Reservoir primary production. In: THORNTON, K. W.; KIMMEL, B. L.; PAYNE,
F. E. [eds] Reservoir Limnology: Ecological Perspectives. Wiley \& Sons, New York, USA, pp. 133-194.

KOROLEFF, F. 1976. Determination of nutrients: 8. Total and organic nitrogen. In: GRASSHOFF, K. (ed). Methods of Sea Waters Analysis. pp. 167177. Verlag Chemie, New York.

LEWIS, W. M. 1973. The Thermal Regime of Lake Lanao (Philippines) and its Theoretical Implications for Tropical LAKES1. Limnology and Oceanography, v. 18, n. 2, p. 200-217.

LOPES, M. R. M.; BICUDO, C. E. D. M.; FERRAGUT, M. C. 2005. Short term spatial and temporal variation of phytoplankton in a shallow tropical oligotrophic reservoir, southeast Brazil. Hydrobiologia, v. 542, n. 1, p. 235-247.

LOPES, M. R. M.; FERRAGUT, C.; MATTOS BICUDO, C. E. D. 2009. Phytoplankton diversity and strategies in regard to physical disturbances in a shallow, oligotrophic, tropical reservoir in Southeast Brazil. Limnetica, v. 28, n. 1, p. 159-174.

LÓPEZ, N.; RIVERA RONDÓN, C. A.; ZAPATA, Á.; JIMÉNEZ, J.; VILLAMIL, W.; ARENAS, G.; RINCÓN C.; SÁNCHEZ, T. 2012. Factors controlling phytoplankton in tropical highmountain drinking-water reservoirs. Limnetica, v. 31 , n. 2, p. 305-322.

LUND, J. W. G.; KIPLING, C.; LE CREN, E. D. 1958. The inverted microscope method of estimating algal numbers and the statistical basis of estimations by counting. Hydrobiologia, v. 11, n. 2 , p. 143-170.

MACINTYRE, S.; MELACK, J. M. 1988. Frequency and depth of vertical mixing in an Amazon floodplain lake (L. Calado, Brazil). 5 fig. Internationale Vereinigung für theoretische und angewandte Limnologie: Verhandlungen, v. 23, n. 1 , p. $80-85$.

MACKERETH, F. J. H.; HERON, J. T.; TALLING, J. F. 1978. Water analysis: some revised methods for limnologists. Scientific Publication, 36, London, Freshwater Biological Association.

MARGALEF, R. 1983. Limnologia. Barcelona: Omega. 1010p. 
MELACK, J. M. 1979. Temporal variability of phytoplankton in tropical lakes. Oecologia, v. 44, p. 1-7.

MOURA, A. N.; DANTAS, E. W.; OLIVEIRA, H. S. B.; BITTENCOURT-OLIVEIRA, M. D. C. 2011. Vertical and temporal dynamics of cyanobacteria in the Carpina potable water reservoir in northeastern Brazil. Brazilian Journal of Biology, v. 71, n. 2, p. 451-459.

NASELLI-FLORES, L.; BARONE， R. 2005. Water-level fluctuations in Mediterranean reservoirs: setting a dewatering threshold as a management tool to improve water quality. Hydrobiologia, v. 548, n. 1, p. 85-99.

NASELLI-FLORES, L.; PADISÁK, J.; ALBAY, M. 2007. Shape and size in phytoplankton ecology: do they matter? Hydrobiologia, v. 578, n. 1, p. 157 161.

PANNARD, A.; BORMANS, M.; LAGADEUC, Y. 2008. Phytoplankton species turnover controlled by physical forcing at different time scales. Canadian Journal of Fisheries and Aquatic Sciences, v. 65, n. 1, p. 47-60.

REYNOLDS, C. S. 1999. Modelling phytoplankton dynamics and its application to lake management. Hydrobiologia, v. 395, p. 123-131.

REYNOLDS, C. S. 2006. Ecology of Phytoplankton. Cambridge: Cambridge University Press. 564p.

SHAFIK, H.; HERODEK, S.; PRESING, M.; LAJOS, V. R. S. 2001. Factors effecting growth and cell composition of cyanoprokaryote Cylindrospermopsis raciborskii (Woloszynska) Seenayya et Subba Raju. Algological Studies/Archiv. Hydrobiologie, v. 103, p. 75-93.

SHANNON, C. E.; WEAVER. W. 1949. The mathematical theory of communication. University \& Illinois Press, Urbana. 117p.

SOUZA, M. B. G.; BARROS, C. F.; BARBOSA, F.; HAJNAL, E.; PADISÁK, J. 2008. Role of atelomixis in replacement of phytoplankton assemblages in Dom Helvécio Lake, South-East Brazil. Hydrobiologia, v. 607, n. 1, p. 211-224.

SRH - Secretaria de Recursos Hídricos do Estado de Pernambuco. 2012. Available at: http://www.sirh.srh.pe.gov.br/apacv5/fichareserva torio_web/fichareservatorio_web.php.

STRICKLAND, J. D.; PARSONS, T. R. 1965. A manual of seawater analysis. Can. J. Fish. Aquat. Sci., v. 125, p. 1-185.

SUN, J.; LIU, D. 2003. Geometric models for calculating cell biovolume and surface area for phytoplankton. J. Plankton Res., v. 25, p. 13311346.

TAVERA, R.; MARTÍNEZ-ALMEIDA, V. 2005. Atelomixis as a possible driving force in the phytoplankton composition of Zirahuén, a warmmonomictic tropical lake. Hydrobiologia, v. 533, n. 1, p. 199-208.

TILZER, M. M.; GOLDMAN, C. R. 1978. Importance of mixing, thermal stratification and light adaptation for phytoplankton productivity in Lake Tahoe (California, Nevada). Ecology, v. 59, p. $810-821$.

TOLOTTI, M.; BOSCAINI, A.; SALMASO, N. 2010. Comparative analysis of phytoplankton patterns in two modified lakes with contrasting hydrological features. Aquat. Sci., v. 72, p. 213226.

UTERMÖHL, H. 1958. Zur vervollkommer der quantitativen phytoplankton methodik. Verh. Int. Ver. Theor. Angew. Limnol. 9: 1-38.

VON SPERLING, E. V.; FERREIRA, A. C. S.; GOMES, L. N. L. 2008. Comparative eutrophication development in two Brazilian water supply reservoirs with respect to nutrient concentrations and bacteria growth. Desalination, v. 226, p. 169-174.

WETZEL, R. G.; LIKENS, G. E. 2000. Limological Analyses. 3nd. New York. Ed. Springer Science. 429p. 